\author{
СРЂАН ПЕТРОВИЋ* \\ Филолошки факултет Универзитета у Београду \\ Београд, Србија
}

\title{
МЕТОДИЧКА ПРАКСА У СИСТЕМУ ПРОФЕСИОНАЛНОГ ОСПОСОБЉАВАЊА СТУДЕНАТА РУСИСТИКЕ У СРПСКО ГОВОРНОЈ И СОЦИОКУЛТУРНОЈ СРЕДИНИ*
}

\begin{abstract}
Дати рад представља покушај сагледавања, описа и анализе методичке праксе у систему студија русистике (филологије) у српској говорној средини. Имајући у виду све већу актуелност датог питања са теоријског и практичног аспекта савремене лингводидактике, потребу струке, као и чињеницу да оно до сада није било предмет системских научних истраживања код нас, потоња проблематика размотрена је са теоријског, евалуационог и практичног аспеката. На тај начин сагледали смо методичку праксу у систему русистичких студија са организационо-концепцијског, структурног, садржинског и нормативно-законског становишта. Одредили смо њену улогу и значај као базичног конституента у практичном оспособљавању и формирању професионалних компетенција будућих наставника руског језика. Настојали смо да представимо савремени пресек реализације методичке праксе у домаћим русистичким универзитетским центрима, доведемо га у везу и упоредимо са моделима практичног оспособљавања будућих наставника на иностраним универзитетима, а најпре у Руској Федерацији.
\end{abstract}

Кључне речи: универзитетска настава, филолошки образовни профил, студије русистике, методичка пракса, практично оспособљавање студената, српска средина

Многим друштвима широм света почетак XXI века донео је значајне промене у друштвено-политичком, културном, економском и научно-техничком погледу. Оне су се одразиле на готово све сфере људске делатности и у одређеној мери утицале на формирање нових обриса савременог друштва у целини. Сферу образовања измене нису мимоишле. Да ће европски универзитетски простор бити суочен са замашним реформама могло се наслутити и крајем прошлог века. Још тада се у развијеним академским срединама активно радило на модернизацији

*srdjan.petrovic@fil.bg.ac.rs

** Рад садржи измењене и прилагођене делове мастер рада који је под називом „Методичка пракса на студијама русистике у српској говорној средини” 2014. године одбрањен на Филолошком факултету Универзитету у Београду. 
система студија ${ }^{1}$, затим је усвојен је и потписан читав низ релевантних европских докумената, међу којима се налази и Болоњска декларација, формални правни оквир за до сада готово незапамћено свеобухватну реформу високошколског образовања.

У условима динамичног развоја и горенаведених промена конституише се нова концепција образовања, те су модернизација и реформисање свих нивоа образовања постали умногоме и нужни. Иако је јасно да дубина и интензитет датих промена нису били (нити могли бити) исти у свим земљама, чињеница је да образовна слика многих средина није остала иста. Перспективе високог образовања виђене су у професионалној оријентацији студија, њиховој интернационализацији и достизању колико је могуће веће интердисциплинарности. Тако су пред универзитетско образовање постављени веома озбиљни задаци које је требало решити и успешно имплементирати на плану његове образовне, истраживачке и иновативне функције.

Нова парадигма образовања, која претпоставља достизање својеврсне стандардизације образовног процеса у ширим европским димензијама, оспособљавање студената за све сложеније и разноврсније захтеве у струци, потребу за високом квалификованошћу и сталним прилагођавањем научно-технолошким достигнућима, несумњиво утиче на обим професионалних компетенција и квалитет кадра који се одшколује, а потоње на тржиште рада где будући наставници страног језика траже запослење.

Владање читавим багажом теоријских знања готово традиционално карактерише свршене академце, међутим, питање њихове практичне оспособљености остаје умногоме отворено. Познати руски стручњак у области професионалног оспособљавања студената, О. А. Абдулина (1990: 75), истиче да је „главни недостатак у оспособљавању данашњих студената некомпатибилност између теоријских знања и њихове практичне примене (üpeвog наш-C.П.)", наводећи да се управо у томе крије разлог слабог овладавања практичним знањима и умењима. Тренутна ситуација у земљи и свету показује да управо дати сегмент професионалних комптенеција студената, њихова практична оспособљеност, постаје један од водећих.

Будући да у српској средини значајан део студената нема могућност (или барем не у довољној мери) практичне примене својих знања и вештина током студирања, значај праксе постаје све очигледнији и све се више прокламује као једно од централних питања у иницијалном образовању будућих наставника страног (руског) језика.

\footnotetext{
${ }^{1}$ Примера ради, није непознаница да је већ осамдесетих и девесетих година постојала могућност реализације програма академске размене попут Erasmus и Socrates.
} 
Питање методичке праксе сврстава се у ред теоријски недовољно разрађених и емпиријски слабије истражених питања русистичке лингводидактике. Иако интересо-вање за дату тематику све више расте током последњих деценија, аутори и радови који расветљавају неко од сродних питања релативно су малобројни (нпр. Б. М. Јесаџањан, Г. М. Агабабјан, Г. П. Кашкорова, Г. М. Мандрикова).

У домаћој русистици бављење датим питањем носило је углавном фрагментарни карактер (К. Кончаревић, В. Раичевић), док у новијој литератури постоји један мастер рад (Петровић 2014) и неколики чланци (Петрович 2014, 2015) посвећени методичкој пракси, углавном аутора датих редова.

Униврзитетско филолошко образовање, као што је познато, веома је сложено и комплексно. Оно поседује својеврсну циклусну структуру, у оквиру које своје место проналази и методичка пракса. Као што се може видети на схеми бр. 1, она припада психолошко-педагошком циклусу.

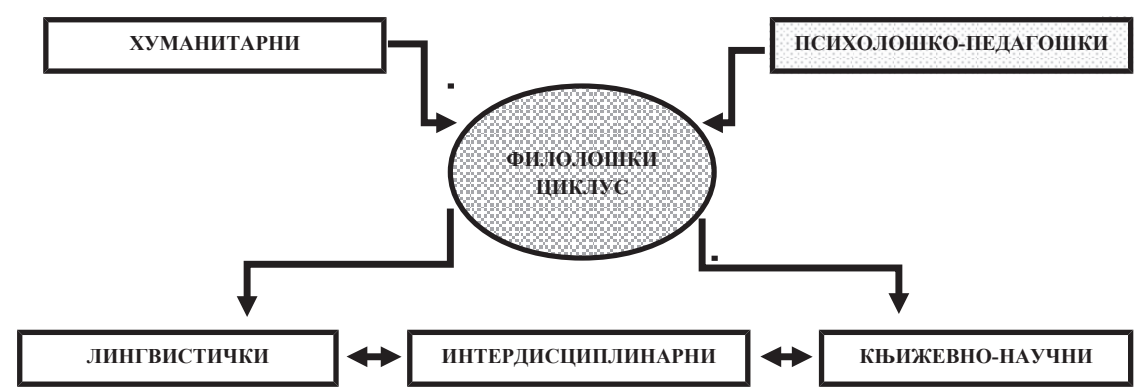

Схема ор. 1. Местио ӣсихолошко-ӣеgаі̄ошкої циклуса

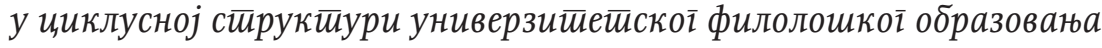
(према Кончаревић 1996: 68)

У систему филолошких (русистичких) студија мейоgичка йракса (даље: МП) представља компоненту која ближе од свих наставних предмета студентима омогућава да закораче у реалност наставничке професије и, колико је то могуће, што веродостојније услове рада. У многим радова теоријског карактера МП интерпретира се као важна карика која стечена теоријска знања повезује са њиховом практичном применом. То је нарочито важно, будући да се ради о остваривању јединства теорије и праксе, битног педагошког принципа.

Налазећи се у дијалектичком односу, међусобно се допуњујући и повезујући, теорија и пракса као два опонирана сегмента остварују јединство које води ка најбољем решењу. Како је теорија потребна пракси, 
тако је пракса потребна теорији. Теорија без праксе не може да провери своје домете и достигнућа, пракса служи теорији као критеријум истинитости, док пракса у теорији проналази свој ослонац и утемељеност, теорија нуди одговарајућа решења за подизање ефективности многих аспеката наставе, те без ње, теорије, пракса може да се претвори у уски практицизам (Поткоњак ред. 1996: 218).

На тај начин методичка пракса као организациона форма наставе на студијама русистике за свој циљ има ефективно и квалитетно - у првом реду практично оспособљавање и припрему студената за успешну професионалну делатност у области савремене наставе руског језика, даљи развој наставничких компетенција за самостални, стручни, наставни и васпитни рад током наставног процеса у школи или другој образовно-васпитној институцији.

Према Б. М. Јесаџањан (1984: 81-92), истакнутом јерменском русисти и афирмисаном стручњаку у области практичног оспособљавања будућих наставника руског језика, издвојили смо следеће задатке методичке праксе:

- утврђивање и продубљљивање методичких, педагошких, дидактичких, психолошких, лингвистичких, лингвокултуролошких и других фундаменталних филолошких знања добијених током теоријске наставе на универзитету, као и њихову адекватну практичну примену у решавању различитих професионалних задатака;

- формирање специфичних методичких, педагошких и других стручних навика и умења наставника руског језика потребних за организцију и реализацију наставно-васпитног рада;

- формирање и развијање личносних и других професионалних особина потреб́них за успешну наставу руског језика;

- овладавање различитим наставним методама, технологијама, облицима рада, стратегијама и тактикама карактеристичних за савремене парадигме образовања и наставу руског језика као њиховог саставног сегмента;

- формирање и развијање (само)критичког мишљења, креативности и истраживачких способности у сфери наставничке делатности, као и навика даљег методичко-педагошког самообразовања и усавршавања;

- комплексније упознавање са професионалном делатношћу наставника руског језика, затим карактеристикама, начином функционисања и структуром наставног процеса у образовном систему у целини, као и на примеру образовно-васпитних установа које ће бити укључене у сам процес методичке праксе студената;

- неговање и развијање љубави студената према својој будућој професији. 
Како конципирање, организација и реализација методичке праксе представљају сложене процесе, неопходно је макар укратко се осврнути на дидактичко-методичке и психолошке претпоставке неопходне за успешно испуњење поменутих процеса.

Образовање на универзитету одликује висок степен заступљености самосталног облика рада студената, који представља и један од основних дидактичких система наставе (Poljak 1970: 144). Прелазећи разне ступњеве образовања - од предшколског, преко основношколског и средњошколског, па све до високошколског, нормативно највишег ступња - самостални облици рада код ученика (а касније студената) постају све присутнији, и то директно пропорционално са повећањем узраста. Једни од битних фактора за формирање професионалне усмерености будућих наставника су самостални облици рада и потреба за самообразовањем (Есаджанян 1984: 10). Током методичке праксе они бивају веома заступљени, те студенти треба да буду припремљени на њих, што у том узрасту најчешће и јесу. Како наводи А. А. Вербицки, управо облици самосталног рада постепено замењују традиционалне, информативне облике рада и представљају својеврсни прелаз од информативног ка активном раду и учењу (према: Попков, Коржуев 2001: 25).

Таква врста рада треба да буде у довољној мери контролисана како не би дошло до занемаривања обавеза од стране студената, као и ради праћења њихове оспособљености за извршење задатака у датим условима. То може бити важно јер самообразовање и самостални рад у значајној мери карактеришу наставничку професију и наставнике неретко прати до краја каријере. То се манифестује, примера ради, путем израда припрема за час, затим процене, одабира и састављања материјала за наставу и ваннаставне активности, научно и стручно усавршавање и др.

Отвореност циља методичке праксе студентима русистике треба да обезбеди формирање подлоге за стицање нових знања и у том смислу их не ограничава. Знања која студенти стекну у оквиру МП треба да им послуже као исходиште за стицање нових знања у будућности (Schmidt 1974: 17). Тај моменат неретко буде у директној вези са наставницима и менторима током праксе, а у највећој мери и њиховом професионалном оспособљеношћу, као и мотивисаношћу за рад са студентима (Кончаревић 1996: 50-51). Сваком добром методичару је јасно колико је велика улога предметних наставника и школских наставника-ментора током МП, стога је на високошколским институцијама велика одговорност у погледу одабира компетентног кадра који ће радити са студентима током периода праксе који је за њих од немерљивог значаја.

Значајни фактори у претпостављању успешне концепције и реализације МП јесу и број часова практичне наставе, број часова у оквиру 
студентског хоспитовања (укључујући пробне и испитни), број студената и начин рада са њима.

У настави сваког предмета, на свим нивоима и у свим образовним профилима, са дидактичко-методичког становишта важно место заузима опремљеност техничким средствима и одговарајућом уџбеничком и приручном литературом. Живимо у времену када је примена различитих техничних достигнућа изузетно велика. Постоји богат избор техничких и других средстава за осавремењавање наставног процеса. Током методичке праксе студенти треба да буду информисани о њиховом постојању, а у складу са могућностима, нека од њих и да примене приликом креирања свога часа.

Са друге стране, у психолошком погледу током МП студенти треба да формирају и развију (Зимняя 2000: 78; Корнева 2006: 2) навике природног понашања током часа са различитим узрасним групама ученика, затим способност рада са ученицима различитог успеха у школовању, социјалног статуса, националности, пола, вероисповести и др., а уз поштовање одговарајућих индивидуално-психолошких карактеристика ученика и специфичности унутрашњег света сваког од њих итд. Само на тај начин могућ је пун психолошки и личносно-оријентисан развој ученика, али и формирања психолошких компетенција код будућих наставника руског језика. Овакав развој умогоме је сродан концепцији личноснооријентисаног приступа у настави који до дан данас има актуелност у многим методичким круговима (исп. Бим 2002: 11-15).

Како би се омогућило адекватно усавршавање студената, код њих је неопходно развијати методичко мишљење (Есаджанян 1984: 4), што значи да пракса мора бити заснована на анализи која ће студентима омогућити промишљање о наставном процесу и својим активностима у њему на објективан, егзактан и валидан начин. Управо (само)критичка анализа сопствене професионалне делатности у многим земљама света представља једну од важнијих компонената професионалног образовања наставника.

Методичка пракса, као што се може закључити, у великој се мери разликује у односу на друге наставне предмете у систему русистичких студија. Њена специфичност одледа се, између осталог, и у погледу структуре. Тако руска лингводидактичка теорија и пракса разликују пасивну и активну методичку праксу.

Пасивна методичка пракса претходи активној и представља „то же, что учебно-ознакомительная практика. Одна из форм профессиональной подготовки преподавателя языка. Предусматривает посещение им занятий в учебных заведениях разного профиля с целью ведения педагогических и психологических наблюдений, обсуждения уроков, внеклассных мероприятий. В отличие от активной практики не предпола- 
гает проведения обучаемыми уроков", док се активна методичка пракса тумачи као „подготовка и проведение уроков иностранного языка студентом, обсуждение уроков и воспитательных мероприятий, проведенных сокурсниками; одна из форм профессиональной подготовки преподавателей иностранного языка" (Азимов, Щукин 2009: 12, 186).

Примећујемо, дакле, да се структура методичке праксе састоји од извесних етапа одн. фаза које студенти треба поступно да пролазе. Ми смо издвојили четири етапе које је могуће разликовати током реализације МП:

1. прва етапа - ближе упознавање студената са релевантним чиниоцима наставног процеса и активности наставника руског језика;

2. друга етапа - пасивна пракса студената;

3. трећа етапа - активна пракса студената;

4. четврта етапа - дискусија анализичко-синтетичког карактера, разговор о постигнућима студената, као и њихова (само)евалуација;

Свака од наведене четири етапе захтева адекватну реализацију и свакој од њих потребно је посветити довољно времена како би МП испунила свој циљ. Уочавамо, према томе, да пракса има и системски карактер с обзиром на њену етапну структуру (Афанасьева, Федотова 2007: 57).

Она може бити организована на различите начине, те и садржаји који постоје током њене реализације могу варирати. Анализом методичке праксе за студенте русистике (Универзитет у Београду, Универзитет у Нишу, Универзитет у Новом Саду, Универзитет у Приштини, Државни институт руског језика „А. С. Пушкин”, Московски државни универзитет „М. В. Ломоносов”, Руски универзитет пријатељства народа, Санктпетербуршки државни универзитет), као и студенте са других нерусистичких катедара Филолошког факултета Београдског Универзитета где се пракса организује ${ }^{2}$ (англисти, германисти, италијанисти, романисти, хиспанисти) ипак се могу извести садржаји који су највише заступљени (Программа ГИРЯ 2010, Программа ГИРЯ 2012, Программа МГУ 2012, Программа РУДН 2008, Программа СПБГУ 2013, Програм ИТА 2012, Програм НЕМ 2012, Програм РУС 2010, Програм РУС 2012, Програм ФРА1 2013, Програм ФРА2 2013, Програм ШПА 2012, СП МАС БГ 2009, СП НИ 2009, СП НС 2009, СП ОАС БГ 2009, СП ПР 2009).

Студенти на самом почетку најпре стичу основна знања везана за наставни процес и професију наставника (у нашој етапној подели - по-

${ }^{2}$ Методичка пракса у домену наставе матерњег (српског) језика и књижевности није разматрана. 
четна етапа праксе). Упознају се са актуелном уџбеничком и приручном литературом, наставним плановима и програмима, циљевима, задацима, садржајима наставног процеса (колико је то могуће за више различитих образовних профила), припремама наставника за час, различитим облицима рада.

Након тога у великом броју случајева следи хоспитовање студена-

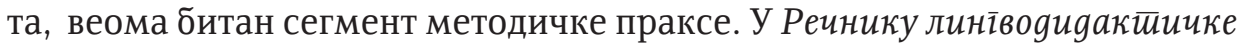
иерминолоїије хоспитовање се интерпретира као „посебан вид високошколског практичног педагошког и дидактичко-методичког образовања студената наставног усмерења за рад у школама, који се састоји у томе да студенти присуствују настави код искусних наставника како би посматрали/пратили и упознали различите методе, поступке и облике наставног рада и друге активности наставника и ученика. Хоспитовање је и час који студент држи у оквиру наставе, а представља предиспитну обавезу из методике наставе страног језика" (Раичевић 2011: 222). Наведена дефиниција недвосмислено указује на изузетан значај хоспитовања током праксе из ког неретко произилази и следећа активност. У питању је писање или попуњавање дневника методичке праксе.

Након хоспитовања студенти пишу дневник методичке праксе који представља документ у ком студенти бележе своје опсервације везане за похађане часове и активности у партнерским институцијама (= школама) током праксе. Садржаји који су заступљени у том смислу превасходно се тичу елемената као што су описивање и одређивање типа часа, циља, организације часа и његове артикулације, опсервације о броју ученика и сваком делу часа засеб́но (уводни део, централни, примарно утврђивање, завршни део часа и задавање домаћег задатка), затим навођење метода и облика рада, виђење дисциплине на часу, активности ученика, односа наставника са њима, као и понашање наставника.

Веома значајна компонента праксе јесте држање пробног часа, једног и више (или његово снимање). Број пробних часова углавном варира у зависности од многих фактора. Навешћемо само неке од њих: техничке могућности, број студената, број наставника и школа са којима је успостављена сарадња. Јасно је да већи број пробних часова може утицати на виши ниво практичне оспособљености студената.

Као најважнији део методичке праксе многи стручњаци наводе држање испитног часа. У српској говорној средини заступљен је и термин йоказни иас, верујемо услед аналогије са руским језиком (рус. показательный урок). Мишљења смо да је подесније користити термин ис$\bar{u} и \bar{u} н и$ иас јер боље осликава суштину дате врсте часа, а и налази већу примену у другим домаћим стручним круговима. Испитни час би требало да представља одраз свеукупног рада и залагања студента, премда не нужно. Сваки час представља ситуацију за себе, те једно успешно 
држање часа не гарантује да ће то сигурно бити случај и сваки наредни пут. Студент током испитног часа мора да размишља о великом броју фактора: организацији времена, успостављању дисциплине, материји одн. градиву, радној способности ученика ${ }^{3}$, затим о сопственом држању, изражавању, ауторитету, језичким вештинама итд. Зато је важно студентима предочити значај припреме за час, писања припрема за њих, док континуирано усавршавање и рад на себи немају ништа мању улогу. То је једини начин за успешну реализацију часа.

Након држања пробног и(ли) испитног часа у великом броју случајева пракса се завршава. Постоје модели МП (углавном у Русији) који након датих обавеза предвиђају организовање завршне дискусије о утисцима и искуствима са праксе, што сматрамо добрим, као и креирање сопственог портфолија. Он укључује састављање и достављање документације у вези са самом праксом, искуствима, активностма и (само)евалуацији (в. Кашкорова, Мандрикова 2005: 114-127).

Током реализације праксе могу се срести и елементи попут учествовања у различитим видовима ваннаставних активности (нпр. увид у наставну документацију, прегледање тестова, додатна или допунска настава, организација или посета школским приредбама, припрема за такмичења и сл.), самосталнога састављања дидактичког материјала и писања рецензије неког од актуелних уџбеника.

Методичка пракса је најчешће организована на четвртој години основних академских студијама (на VII и(ли) VIII семестру), која у систему четверосеместралног извођења наставе припада другој, продужној етапи (где VII и VIII семстар представљају трећи и четврти, систематизујући подниво (в. дет. Кончаревић 2004: 416). Међутим у српској говорној средини није редак случај да се методичка пракса похађа и током мастер академских студија, а у руској чак и на нивоу докторских студија (Программа ГИРЯ 2010).

Издвајање методичке праксе у српској средини постало је тим неопходније с обзиром на чињеницу да према члану 8 Закона о основама сисиема образовања и васиитиања (Сл. гласник РС бр. 72/2009 од 03. септембра 2009. године) студент који од школске 2012/2013. године претендује на рад у основним и средњим школама на територији Републике Србије „мора да има образовање из психолошких, педагошких и методичких дисциплина стечено на високошколској установи у току студија или након дипломирања, од најмање 30 бодова и шести боgова

${ }^{3}$ Током часа она пролази кроз неколике фазе: приступна фаза одн. фаза преласка на нови, радни режим, фаза оптималног рада, фаза напора и манифестације премора (Есаджанян 1991: 140) зато, примера ради, није пожељно централни део градива остављати за завршни део часа. 
ираксе $e^{4}$ у установи, у складу са Европским системом преноса бодова" (Закон 2013).

Појављивање и ступање на снагу овог закона имплицирало је формирање тзв. педагошко-психолошко-методичке (ППМ) групације предмета где једно од централних места несумњиво припада и методичкој пракси. Студенти могу бирати и више предмета из ове групације, али законски минимум представља 30 ЕСПБ из теоријских предмета и 6 ЕСПБ за праксу. Русистичке катедре претежно имају могућност остваривања ових бодова, као и праксе (ППМ БГ 2012, ППМ НС 2012, Правилник 2014б, Програм КМ 2014).

Ипак, мишљење многих стручњака (Dimitrijević 1979: 73, Кончаревић 2002: 74, Богичевић 2007: 131, Кончаревић 2007: 45, Budić 2008: 13) да не постоји довољна функционалност у погледу адекватног професионалног оспособљавања, да се МП студената не посвећује довољно пажње те да није у одговарајућој мери заступљена, ни данас није ништа мање заступљено.

Истраживање поводом ставова наставника и студената о реформи филолошких студија, које су у оквиру већег пројекта Јулијана Вучо и Оливера Дурбаба спровеле на репрезентативном узорку различитих филолошких групација у Републици Србији, показало је, између осталог, и незадовољство студената проузроковано недостатком праксе, недовољним бројем часова у оквиру исте, као и слабом повезаношћу теоријских садржаја са практичном применом у професији (Вучо, Дурбаба 2012: 133). Стога колико год да је, са једне стране, пракса издвојена као посебан предмет и препозната као битна у иницијалном образовању будућих наставника страног (руског) језика, питање њене довољне заступљености и адекватне реализације на филолошким студијама и даље је у великој мери отворено.

Методичка пракса на русистичким катедрама у српској говорној средини нема исти степен заступљености. У зависности од конкретног универзитета многи параметри овог наставног предмета варирају и нису оптимални (в. Табелу бр. 1). Увидом у студијске програме, одабране према транверзалном принципу, те коришћене на русистичким катедрама у академској 2013/2014. години (СП МАС БГ 2009, СП НИ 2009, СП НС 2009, СП ОАС БГ 2009, СП ПР 2009) увидели смо да је МП заступљена:

(a) у оквиру теоријске наставе на основним академским студијама на Универзитету у Нишу (VII семестар) и Универзитету у Приштини (VIII семестар);

(б) као посебан предмет на основним академским студијама на Универзитету у Новом Саду (VIII семестар);

${ }^{4}$ Издвајање наше - С.П. 
(в) као посебан предмет на мастер академским студијама на Универзитету у Београду (IX семестар).

Из свега наведеног можемо потврдити да настава овог предмета на русистичким катедрама у земљи умногоме варира и да није оптимална.

Сам назив предмета у коме је заступљена методичка пракса та-

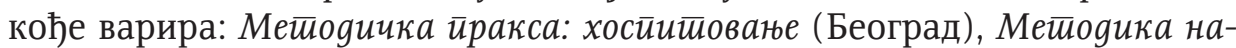

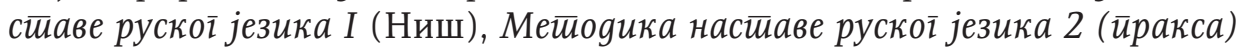
(Нови Сад) и Мейоgика насйаве рускої језика 2.

Табела бр. 1

\begin{tabular}{|c|c|c|c|c|c|}
\hline & \multirow{2}{*}{ Београд } & \multirow{2}{*}{ Ниш } & \multirow{2}{*}{ Нови Сад } & \multirow[b]{2}{*}{ Приштина } \\
\hline & & & & & \\
\hline \multicolumn{2}{|c|}{$\begin{array}{l}\text { основне академске } \\
\text { студије (VII семестар) }\end{array}$} & & + & & \\
\hline \multicolumn{2}{|c|}{$\begin{array}{l}\text { основне академск } \\
\text { студије (VIII семестар) }\end{array}$} & & & + & + \\
\hline \multicolumn{2}{|c|}{$\begin{array}{l}\text { мастер академске } \\
\text { студије (IX семестар) }\end{array}$} & + & & & \\
\hline \multirow{2}{*}{$\begin{array}{l}\text { статус } \\
\text { предмета }\end{array}$} & обавезан & & + & + & + \\
\hline & изборни & + & & & \\
\hline \multicolumn{2}{|c|}{$\begin{array}{l}\text { у оквиру теоријске } \\
\text { наставе }\end{array}$} & & + & & + \\
\hline \multicolumn{2}{|c|}{ посебан предмет } & + & & + & \\
\hline \multicolumn{2}{|c|}{ тип предмета } & иП & CA & $\mathrm{CA}$ & $\mathrm{TM}$ \\
\hline \multicolumn{2}{|l|}{ условност } & не & да & да & да \\
\hline \multicolumn{2}{|l|}{ ЕСПБ } & 12 & 7 & 6 & 2 \\
\hline
\end{tabular}

Према статусу предмета једино у Београду методичка пракса има статус изборности, што је потпуно оправдано у складу са степеном студија на ком се може похађати. Предмети који садрже МП, делимично или у целини, на основним академским студијама припадају различитим групацијама предмета: стручно апликативној (Нови Сад, Ниш) или теоријско-методолошкој (Приштина). 


\begin{tabular}{|c|c|c|c|c|c|c|c|c|c|c|c|c|}
\hline & \multicolumn{4}{|c|}{$2011 / 2012$} & \multicolumn{4}{|c|}{$2012 / 2013$} & \multicolumn{4}{|c|}{$2013 / 2014$} \\
\hline & БГ & НИ & $\mathrm{HC}$ & ПР & Бг & ни & $\mathrm{HC}$ & ПР & БГ & ни & $\mathrm{HC}$ & ПР \\
\hline држање испитног часа & + & + & + & + & + & + & + & + & + & + & + & + \\
\hline држање пробног часа & $(+)$ & - & + & + & $(+)$ & + & + & + & + & + & + & + \\
\hline снимање пробног часа & - & - & - & - & - & - & - & - & + & - & - & - \\
\hline $\begin{array}{l}\text { писање дневника/извештаја } \\
\text { са одслушаних часова }\end{array}$ & + & + & - & - & + & + & - & - & - & + & - & - \\
\hline писање припреме за час & + & + & + & + & + & + & + & + & + & + & + & + \\
\hline писање планова рада & + & - & - & - & + & - & - & - & - & + & - & + \\
\hline писање рецензије уџбеника & + & - & - & - & + & - & - & - & - & - & - & - \\
\hline припрема испитног часа & + & + & + & + & + & + & + & + & + & + & + & + \\
\hline $\begin{array}{l}\text { састављање сопствених } \\
\text { материјала, задатака и вежбања }\end{array}$ & + & - & + & - & + & + & + & - & + & + & + & - \\
\hline
\end{tabular}


Садржински план методичке праксе на русистичким катедрама у српској говорној средини у одређеној мери је уједначен, премда не у свим сегментима, што се јасно види у табели бр. 2. У школској 2013/2014. години ситуација је била следећа:

На тај начин може се приметити да све русистичке катедре у српској говорној средини током методичке праксе у 2013/2014. години имају заступљене следеће сегменте: писање припрема за час, држање пробног часа, писање припреме за испитни час и држање испитног часа. Једино београдски студенти имају снимање пробног часа, једино нишки пишу дневник методичке праксе, а једино нишки и приштински студенти током методичке праксе имају заступљено писање планова рада. Састављање сопствених материјала, задатака и вежбања није заступљено само код приштинских русиста, док писање рецензије уџбеника није заступљено ни на једном универзитету.

Методичка пракса за будуће наставнике руског језика, као што се може закључути, има изузетно велику улогу. Она представља један од централних сегмената њихвог курикулума и препозната је као важна чак и са становишта законских норматива. На студијама русистике у српској говорној средини пракса није у довољној мери заступљена. Увидом у студијске програме русистичких катедара на нивоу земље уочили смо да њен степен заступљености, обим, дужина трајања и други иманентни фактори варирају у зависности од конкретног универзитета и нису оптимални. Надамо се да ће овај рад моћи да послужи и као подстицај за расветљавање других важних питања везаних за методичку праку, а ако у томе буде успео, сматраћемо да је испунио један од свих главних циљева.

\section{ИЗВОРИ}

\section{А. НАСТАВНИ ПЛАНОВИ И ПРОГРАМИ}

Программа ГИРя 2010 - Рабочая программа Пеgагогической практики, Основная образовательная программа послевузовского профессионального образования (аспирантуры) по специальности 13.00.02 - теория и метолика обучения и воспитания (русский язык как иностранный), Государственный институт русского языка им. „А. С. Пушкина”, Москва, 2010, 82-86.

Программа ГИРЯ 2012 - Программа профессиональной переподготовки для выполнения нового вида профессиональной деятельности Препоgавание русского языка как иностранного, Государственный институт русского языка им. „А. С. Пушкина”, Москва, 2012.

Программа МГУ 2012 - Программа производственной практики Пассивноактивная пеgагогическая практика (магистратура: 1 год обучения, 2 
семестр) по направлению подготовки «Филология», МП «Русский язык как иностранный: лингводидактические и лингвокультурологические основы преподавания», Московский государственный университет им. М. В. Ломоносова, филологический факультет, Москва (интерни документ Катедре).

Программа РУДН 2008 - Программа Педагогической практики (РКИ) для очного и очно-заочного отделений (бакалавриат), Российский университет дружбы народов, Москва.

Программа СПБГУ 2013 - Программа произдводственной (педагогической) практики студентов-бакалавров, Санкт-Петербургский государственный университет, факультет русского языка как иностранного и методики его преподавания, Санкт-Петербург (интерни документ Факултета).

Програм КМ 2014 - Проі̄рам за йеgаїошко, йсихолошко и мейоgичко осйособљаване насйавника. Универзитет у Приштини, Филозофски факултет, Косовска Митровица, 2014.

Програм ИТА 2012 - Мастер академске студије Филолошког факултета Универзитета у Београду. Студијски програм Језик, књижевност, култура. Програм предмета Методичка пракса: хоспитовање, Катедра за италијанистику, Београд (интерни документ Катедре).

Програм НЕМ 2012 - Мастер академске студије Филолошког факултета Универзитета у Београду. Студијски програм Језик, књижевност, култура. Програм предмета Методичка пракса: хоспитовање, Катедра за германистику, Београд (интерни документ Катедре).

Програм РУС 2010 - Основне академске студије Филолошког факултета Универзитета у Београду. Студијски програм Руски језик и књижевност. Програм предмета Практична методика наставе руског језика, Катедра за славистику, Београд (интерни документ Катедре).

Програм РУС 2012 - Мастер академске студије Филолошког факултета Универзитета у Београду. Студијски програм Језик, књижевност, култура. Програм предмета Методичка пракса: хоспитовање, Катедра за славистику, Београд (интерни документ Катедре).

Програм ФРА1 2013 - Основне академске студије Филолошког факултета Универзитета у Београду. Студијски програм Језик, књижевност, култура. Програм предмета Методика наставе француског језика 1, Катедра за романистику, Београд (интерни документ Катедре).

Програм ФРА2 2013 - Основне академске студије Филолошког факултета Универзитета у Београду. Студијски програм Језик, књижевност, култура. Програм предмета Методика наставе француског језика 2, Катедра за романистику, Београд (интерни документ Катедре).

Програм ШПА 2012 - Мастер академске студије Филолошког факултета Универзитета у Београду. Студијски програм Језик, књижевност, култура. Програм предмета Методичка пракса: хоспитовање, Катедра за иберијске студије, Београд (интерни документ Катедре).

СП МАС БГ 2009 - Студијски програм Језик, књижевност, култура, Мастер академске студије Филолошког факултета Универзитета у Београду (распо- 
ред предмета по семестрима и спецификација предмета за књигу предмета), Београд (интерни материјал Факултета).

СП НИ 2009 - Студијски програм Департмана за руски језик и књижевност Филозофског факултета Универзитета у Нишу. Основне академске студије (распоред предмета по семестрима и годинама студија и спецификација предмета за књигу предмета), Ниш. Доступно на: <http://www.filfak.ni.ac. rs/preuzimanje/nastavni-planovi-i-literatura/osnovne-akademske-studije/ ruski-jezik-i-knjizevnost/raspored-predmeta-po-semestrima-i-godinamastudija/preuzimanje.html>, <http://www.filfak.ni.ac.rs/preuzimanje / knjige-predmeta/osnovne-akademske-studije/ruski-jezik-i-knjizevnost/ivgodina/preuzimanje. html> (08.07.2014).

СП НС 2009 - Структура студијских програма Филозофског факултета Универзитета у Новом Саду. Студијски програм Катедре за руски језик и књижевност. Основне академске студије (структура студијског програма и спецификација предмета за књигу предмета), Нови Сад. Доступно на: <http://www.ff.uns.ac.rs/studije/studijski_pr ogrami/OS2008/RUSKI2008. pdf>, <http://www.ff.uns.ac.rs/studije/studijski_programi/OS 2008/ RUSKI_OAS_SPEC.pdf> (08.07.2014).

СП ОАС БГ 2009 - Студијски програми Филолошког факултета. Преглед предмета по програмима и профилима за 2009/2010. Студијски програм Језик, књижевност, култура, Руски језик, књижевност, култура. Основне академске студије (распоред предмета по семестрима и годинама студија и спецификација предмета за књигу предмета), Београд (интерни материјал Катедре).

СП ПР 2009 - Студијски програм Катедре за руски језик и књижевност Филозофског факултета Универзитета у Приштини са седиштем у Косовској Митровици. Основне академске студије (распоред предмета по семестрима и годинама студија и спецификација предмета за књигу предмета), Косовска Митровица (интерни материјал Катедре).

\section{В. ЗАКОНИ И ПРАВИЛНИЦИ}

Закон 2013 - Закон о основама система образовања и васпитања. - Службени гласник Републике Србије бр. 72/09, 52/11 и 55/2013. Доступно на: <http://www.mpn.gov.rs/ima ges/content/prosveta/pravna_akta/ZAKON_ O_OSNOVAMA_SISTEMA_2013_.doc> (08.07.2014)

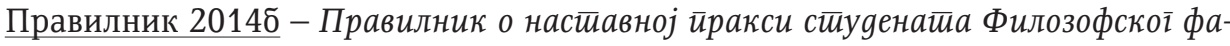
кулйейа у Нишу, Универзитет у Нишу, Филозофски факултет, Ниш (интерни документ факултета).

\section{Г. СТРАТЕШКА И ДРУГА ДОКУМЕНТА}

ППМ БГ 2012 - Листа предмета из педагошко-психолошко-методичке области. Прилог уз тачку 14/V редовна седница Изборног и Научно-наставног већа Филолошког факултета Универзитета у Београду. (интерни документ), 2012. 


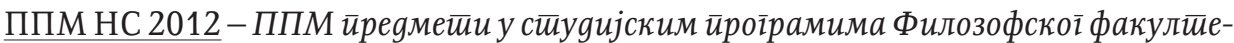

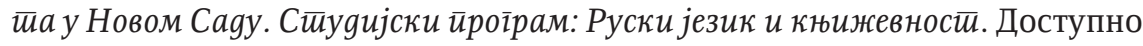
на: <http://www.ff.uns.ac.rs/fakultet/Sistem_obezbedjenja_kvaliteta/Mere/ ppm_predmeti_u_studijskim_programima.pdf> (08.07.2014)

\section{ЛИТЕРАТУРА}

Абдуллина, О. А. (1990). Общепеgагогическая подготовка уиителя в системе высшего пеgагогического образования: яля пеgагогических специальностей высших уиебных завеgений. Москва: Просвещение.

Азимов, Э. Г., Щукин, А. Н. (2009). Новый словарь метояических терминов и понятий (теория и практика обучения языкам). Москва: Издательство ИКАР.

Афанасьева, О. Ю., Федотова, М. Г. (2007). „Педагогическая практика как компонент профессиональной-подготовки учителя иностранного языка", Пеgагогика и психология, 51-61.

Бим, И. Л. (2002). Личностно-ориентированный подход - основная стратегия обновления школы, Иностранные языки в школе, 11-15.

Богичевић, Д. (2007). „Методичка пракса студената као фактор припремања за

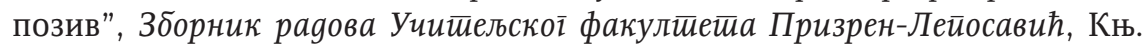
$1,131-136$.

Вучо, J. Д., Дурбаба, О. М. (2012). „Криза филолошких студија: ставови студената и наставника о усклађености студијских садржаја, наставе и потреба савременог друштва", Савремено gрушӣво и криза йроуиавања језика и книжевности и, 123-139.

Есаджанян, Б. М. (1984). Науиные основы метооической поgготовки препоgавателей русского языка как неро оного. Москва: Русский язык.

Есаджанян, Б. М. (1991). „К вопросу о критериях анализа и оценки урока неродного языка", Общая метоgика обуиения иностранным языкам: Хрестоматия. Москва: Русский язык.

Зимняя, И. А. (2000). Пеgагогическая психология. Уиебник яля вузов. Москва: Логос.

Кашкорова, Г. П., Мандрикова, Г. М. (2005). Лингвоgияактика: система поgтоговки препо аавателя русского языка как иностранного: уиебное пособие. Новосибирск : Изд-во НГТУ.

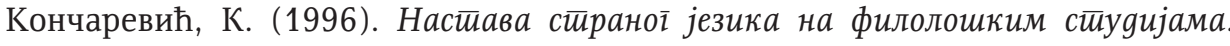
Београд: Филолошки факултет у Београду.

Кончаревић, К. (2002). „Русистичко образовање данас: проблеми и перспективе", Филолошки йреїлеg, XXIX, 1, 67-78.

Кончаревић, К. (2004). Савремена насйава руской језика: саgржаји, орі̄анизаиија, облиน, Београд: Славистичко друштво Србије.

Кончаревић, К. (2007). „О неким комуникативним, конструктивним, организационим и гностичким компетенцијама наставника страног језика", Uloga nastavnika u savremenoj nastavi jezika: zbornik radova, 17-32.

Корнева, Л. В. (2006). Психологические основы пеgагогической практики. Москва: Владос. 
Петровић, С. (2014). Мейоgичка ирракса на стиуяијама русистикке у срйској їоворној среgини. Необјављени мастер рад. Београд: Филолошки факултет Универзитета у Београду.

Петрович, С. (2014). „О неким аспектима конципирања методичке праксе за студенте русистике у српској говорној средини", Славянские gиалоги : межяунаровный сборник науиных статей молоgых уиеных (отв. ред. А. Ю. Маслова). - Саранск: Издательство Мордовского университета, 94-103.

Петрович, С. (2015). „Педагогическая практика для студентов-русистов в сербской среде: актуальное состояние и перспективы", Русский язык как инославянский, 7, 104-115.

Попков, В. А., Коржуев, А. В. (2001). Дияактика высшей школы. Москва: Издательский центр „Академия”.

Поткоњак, Н. (ред.), (1996). Пеgаїошки лексикон. Београд: Завод за уџбенике и наставна средства.

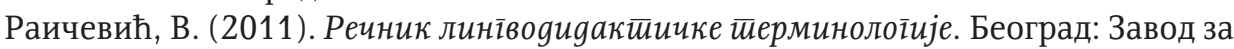
уџбенике, 2011.

Budić, S. (2008). „Modeli praktično-pedagoškog osposobljavanja studenata i razvoj njihovih kompetencija za buduće delovanje u praksi", Didaktičko-metodički aspekti studentske prakse u partnerskim relacijama fakulteta i škola. Novi Sad: Filozofki fakultet.

Poljak, V. (1990). Didaktika. Zagreb: „Školska knjiga”.

Schmidt, V. (1972). Visokoškolska didaktika. Zagreb: „Pedagoško-književni zbor”.

\section{Srđan Petrović}

\section{PRACTICE TEACHING IN THE SYSTEM OF PROFESSIONAL TRAINING FOR RUSSIAN LANGUAGE STUDENTS IN SERBIAN SPEAKING ENVIRONMENT AND SERBIAN SOCIOCULTURAL ENVIRONMENT}

\section{Summary}

This paper is an attempt at complex understanding, description and analysis of the practice teaching in Russian studies (philology) in the Serbian speaking environment and Serbian sociocultural environment. Considering the increasing interest in the given issue from the theoretical and practical aspects of modern linguodidactics, the need of the profession, as well as the fact this topic has not previously been the subject of systematic scientific research in our country, we studied the issue in question from three aspects: theoretical, evaluational and practical.

In this paper hat sense, we have tried to analyze the practicum as a component of philological studies from the organizational-conceptual, structural, con- 
tent and legislative-normative aspect, to establish its role and importance as the basic constituent in practical training of future Russian language teachers and in shaping of their professional competences. We have tried to present a section of modern realizations of practice teaching in all domestic university centers for Russian studies, and to associate and compare it with models of practical training of future teachers in foreign university centers (primarily in the Russian Federation) and departments specializing in other languages in the country.

Key words: practice teaching, university teaching, philological education profile, Russian studies, practical training for students, Serbian environment 